\title{
Diversity of Foliar Phytophthora Species on Rhododendron in Oregon Nurseries
}

B. J. Knaus, Horticultural Crops Research Unit, United States Department of Agriculture-Agricultural Research Service (USDA-ARS), Corvallis, OR; V. J. Fieland, Department of Botany and Plant Pathology, Oregon State University, Corvallis; K. A. Graham, Horticultural Crops Research Unit, USDA-ARS, Corvallis, OR; and N. J. Grünwald, Horticultural Crops Research Unit, USDA-ARS, and Department of Botany and Plant Pathology and Center for Genome Research and Biocomputing, Oregon State University, Corvallis

\begin{abstract}
Knaus, B. J., Fieland, V. J., Graham, K. A., and Grünwald, N. J. 2015. Diversity of foliar Phytophthora species on Rhododendron in Oregon nurseries. Plant Dis. 99:1326-1332.

The genus Phytophthora contains some of the most notorious plant pathogens affecting nursery crops. Given the recent emergence of the sudden oak death pathogen Phytophthora ramorum, particularly in association with Rhododendron spp., characterization of Phytophthora communities associated with this host in nursery environments is prudent. Many taxa may present symptoms similar to $P$. ramorum but we do not necessarily know their identity, frequency, and importance. Here, we present a survey of Phytophthora taxa observed from seven nurseries in the U.S. state of Oregon. Incidence and diversity of Phytophthora communities differed significantly

among nurseries and among seasons within nursery. The taxa $P$. syringae and $P$. plurivora were widespread and detected at most of the nurseries sampled. Nine other taxa were also detected but were found either in a single nursery or were shared among only a few nurseries. Characterization of the Phytophthora communities present in nurseries is an important step toward understanding the ecology of these organisms as well as an aid to nursery managers in determining what risks may be present when symptomatic plants are observed. This study builds on an increasing literature, which characterizes Phytophthora community structure in nurseries.
\end{abstract}

The greenhouse and nursery industry in the U.S. state of Oregon is perhaps one of the most important agricultural industries in the state. During 2011, its worth was U.S.\$742 million, down from approximately $\$ 1$ billion in 2007 (33,34). This represented 14\% of the state's agricultural production in 2011. Therefore, management and mitigation of plant pathogens in this industry presents an important role in the state's economy. A fundamental task in this management and mitigation is characterization of the plant pathogens present in these nurseries in order to develop best management practices and determine critical control points for implementation of systems approaches $(14,35)$.

Plant pathogens in the genus Phytophthora play an important role in the nursery industry. For example, the nursery industry was severely affected by the recent emergence of the sudden oak death pathogen Phytophthora ramorum due to the fact that this pathogen is subject to federal quarantine $(17,48)$. Several studies have shown that $P$. ramorum has emerged repeatedly in Europe and North America and provided compelling evidence that the nursery trade is moving the pathogen with nursery shipments $(12,15,30,38,46)$. Export of host plant taxa among states in the United States is regulated to prevent further spread of this pathogen. The sudden oak death pathogen has a broad host range, including many taxa important to the nursery industry $(18,20,45)$. P. ramorum is primarily a foliar pathogen on nursery crops such as Rhododendron, Camellia, and Pieris spp. $(17,37)$. However, determining whether foliar lesions observed on a particular plant species may be attributable to the regulated P. ramorum or any of the nonregulated species of Phytophthora presents a challenge. Thus, understanding of the community of foliar-infecting Phytophthora taxa in nurseries represents an important first step in development and implementation of best management practices.

Currently, Phytophthora taxa are identified either by classical morphological analysis or sequencing of the internal transcribed

Corresponding author: N. J. Grünwald;

E-mail: grunwaln@science.oregonstate.edu

Accepted for publication 25 February 2015.

http://dx.doi.org/10.1094/PDIS-09-14-0964-RE

(C) 2015 The American Phytopathological Society spacer (ITS) region or cox spacer regions $(19,27)$. Identification by classical morphological techniques is tedious and slow (10), while identification by sequencing is expensive and, at times, difficult if hybrids are present that cannot be sequenced without cloning $(6,11)$. Thus, there is a need for development of cheap, rapid assays for detection. Restriction assays revealing fragment length polymorphism following polymerase chain reaction (PCR) amplification are a viable tool if species diversity expected is moderate; that also works for hybrid taxa $(7,29)$. To date, nurseries in the northwestern United States have revealed moderate diversity of Phytophthora spp. (36) and, thus, a diagnostic assay for the species for Oregon nurseries based on PCR restriction fragment length polymorphism (RFLP) might be viable.

Here, we present a survey of Phytophthora communities present on Rhododendron foliage in seven commercial nurseries located in the U.S. state of Oregon. Directed searches were performed to attempt to identify symptomatic Rhododendron plants; that is, plants possessing leaves with lesions characteristic of foliar Phytophthora infection. Our work had two objectives: (i) development and validation of a PCR-RFLP assay for convenient identification of Phytophthora taxa commonly found in the northwestern United States and (ii) testing of the hypothesis that Phytophthora communities in Rhododendron nurseries in Oregon differ significantly between nurseries as well as between two seasons, spring and fall.

\section{Materials and Methods}

Sampling strategy. Phytophthora spp. were systematically sampled, focusing on lesions observed in contiguous blocks of Rhododendron plants in commercial nurseries. In total, seven nurseries were sampled in spring and fall. These nurseries represent a majority of Oregon counties in the Willamette Valley, where the majority of Oregon nurseries are located. Three blocks of Rhododendron plants were sampled in each nursery following a zig-zag pattern through each block. Each block typically consisted of one greenhouse, hoop house, or other group of contiguous Rhododendron plants. Sampled plants were spaced a minimum of 3 to $6 \mathrm{~m}$ apart. Three to four leaves were collected from each of approximately 20 symptomatic plants.

Phytophthora isolation and clean culturing. Symptomatic leaves were collected from each nursery and stored at room temperature overnight. Leaves were surface sterilized by washing in a $2 \%$ household bleach solution $(0.12 \%$ Sodium hypochlorite, $\mathrm{NaClO})$ for $15 \mathrm{~s}$ and rinsed repeatedly in deionized water. A flame-sterilized paper 
hole punch was used to cut five to eight disks from the leading edge of growth of leaf lesions. Disks were embedded in the Phytophthora selective medium V8 PARP (20\% filtered V8 juice, pentachloronitrobenzene at $100 \mathrm{ppm}$, sodium ampicillin at $250 \mathrm{ppm}$, rifampicin at $10 \mathrm{ppm}$, and pimaricin at $10 \mathrm{ppm})(22)$ and incubated at $20^{\circ} \mathrm{C}$ until hyphal growth was observed (typically 5 to 7 days). Hyphal tips from the leading edge of these cultures were subcultured on V8 PARP selective media to obtain a clean culture.

PCR-RFLP assay development. To rapidly identify Phytophthora taxa, a PCR restriction assay was developed. The restriction assay was designed using the ITS for Phytophthora sequences from the National Center for Biotechnology Information (NCBI; http://www. ncbi.nlm.nih.gov/) and Phytophthora-ID (19). A group of all Phytophthora spp. expected in Oregon on Rhododendron spp. and observed in nurseries $(19,35,36)$ was screened for informative restriction enzymes yielding unique restriction patterns using Geneious (v.6.1.3; Biomatters Inc., San Francisco). A combination of loci and enzymes were developed, given that no single locus and enzyme combination could distinguish all taxa of interest to us (Table 1). A supplementary table with restriction size data and GenBank accessions is deposited at figshare (24).

Taxonomic validation based on sequencing. The new restriction assay for nursery Phytophthora spp. was validated with direct sequencing of the ITS regions of the unknown Phytophthora cultures and by inclusion of previously identified species from our culture collection as references (19). Tissue was collected from aerial hyphae collected from the surface of cultured isolates using a sterile toothpick and transferred to $100 \mu \mathrm{l}$ of deionized water. The hyphae containing water solution was boiled for $5 \mathrm{~min}$ at $95.9^{\circ} \mathrm{C}$ on an ABI 9700 or Veriti thermocycler (Applied Biosystems Inc., Foster City, CA). Loci were amplified using 1 to $3 \mathrm{ng}$ of DNA, a primerspecific concentration of $\mathrm{MgCl}_{2}$ (Table 1), $0.2 \mathrm{mM}$ each dNTP, $0.4 \mu \mathrm{M}$ primers (Table 1), $1.25 \mathrm{U}$ of Taq polymerase (Genscript Corporation, Piscataway, $\mathrm{NJ}$ ), and molecular-grade water to attain a final reaction volume of $25 \mu$ l. The reaction was performed with an initial denaturation at $94^{\circ} \mathrm{C}$ for 3 min followed by 35 cycles consisting of $1 \mathrm{~min}$ of denaturation at $94^{\circ} \mathrm{C}, 1 \mathrm{~min}$ of annealing at a primerspecific temperature (Table 1 ), and $1 \mathrm{~min}$ of extension at $72^{\circ} \mathrm{C}$. A final extension step was performed at $72^{\circ} \mathrm{C}$ for $10 \mathrm{~min}$. Reactions were performed on an ABI 9700 or Veriti thermocycler (Applied Biosystems Inc.). All digests were performed according to the manufacturer's directions (New England Biolabs, Ipswich, MA). Digested DNA was visualized on a $2 \%$ agarose gel (wt/vol) with a $1-\mathrm{kb}$-plus ladder (Life Technologies, Grand Island, NY) run in $1 \times$ Trisacetate-EDTA buffer for $2.0 \mathrm{~h}$ at $60 \mathrm{~V}$.

When an unexpected fragment pattern was observed (i.e., one that was not predicted by Geneious or which had not been previously observed), the amplified ITS locus was sequenced. Approximately $20 \%$ of the isolates with expected fragment patterns were also sequenced for quality control purposes. Sequencing was performed at Oregon State University's Center for Genome Research and Biocomputing using ABI's Big Dye Terminator chemistry and sequenced on an ABI 3730 capillary sequencing machine (Applied Biosystems Inc.). Sequences were identified to species using Phytophthora-ID (19), a web-based BLAST (2) tool with a Phytophthora-specific database. One exception to species-level detection was $P$. pini and $P$. citricola III, which share identical ITS sequences (21) and, therefore, are not distinguished here. Samples which shared greater than a $99.5 \%$ sequence identity were considered matches, while samples with $<99.5 \%$ and $>99 \%$ sequence identity were identified to the most similar species and given a "-like" designation.

Validation of a novel $P$. syringae ITS sequence. A sequence which did not match other Phytophthora ITS sequences was detected during the project. This sequence was suspected to belong to the taxon $P$. syringae, based on morphological examination. In order to validate this variant, three additional regions were sequenced: the $\beta$-tubulin gene amplified with primers Btub-F1 and Btub-R1, the coxI gene with primers FM84 and FM85, as well as a region containing the coxII gene and spacer were amplified with primers FM75 and FM80 (Table 1). DNA was purified using the FastDNA kit (MP Biomedicals, LLC, Solon, OH). Amplification reactions for both the coxII and $\beta$-tubulin loci consisted of 1 to $3 \mathrm{ng}$ of DNA template, $1 \times$ Taq buffer with locus-specific $\mathrm{MgCl}_{2}$ concentration (Table 1), $0.2 \mathrm{mM}$ each dNTP, $1.0 \mu \mathrm{M}$ each primer, $1.25 \mathrm{U}$ of Taq polymerase (Genscript Corporation), and molecular-grade water to reach a final volume of $25 \mu \mathrm{l}$. Reactions were conducted on an ABI 9700 or Verity thermal cycler (Applied Biosystems Inc.) under the following conditions: 1 cycle of denaturation at $94^{\circ} \mathrm{C}$ for $3 \mathrm{~min}$ and 35 cycles of $30 \mathrm{~s}$ of denaturation at $94^{\circ} \mathrm{C}, 45 \mathrm{~s}$ of annealing at a locusspecific temperature (Table 1), and $1 \mathrm{~min}$ of extension at $72^{\circ} \mathrm{C}$. These 35 cycles were followed by an extension cycle at $72^{\circ} \mathrm{C}$ for $10 \mathrm{~min}$. Sequencing was performed as described above.

Statistical analyses. A map of Oregon counties sampled was created in $\mathrm{R}$ with the package Maps $(3,40)$. Summaries of nursery diversity were calculated in the $\mathrm{R}$ package vegan $(32,40)$. These included the sample size, richness (number of species), Shannon-Wiener diversity index $(43)$, evenness $(16,26)$ (the Shannon-Wiener index divided by it's maximum expected richness in order to scale it from zero to one), and Simpson's diversity index (44) (i.e., the probability that two individuals sampled at random will be of different species).

We tested the hypothesis that diversity was evenly partitioned among nurseries, as well as among seasons within nurseries, using additive diversity partitioning as implemented in the $\mathrm{R}$ package vegan (32) and discussed by Crist et al. (8) and Lande (25). This analysis is analogous to analysis of variance where a diversity metric is used as the dependent variable. Among-group diversity ( $\beta$-diversity) can be derived from within-group diversity ( $\alpha$-diversity) subtracted from total diversity ( $\gamma$-diversity). This can be made hierarchical by using $\alpha$-diversity at the next highest level as $\gamma$-diversity for that level. We used nursery and season, nested within nursery, as two hierarchical levels. In order to correct for a potentially unbalanced sample, we used diversity estimates weighted by their proportionality. To test for significance, we randomly assigned diversity among the categories and derived our diversity estimates again, repeating this for a total of 999 times.

\section{Results}

Leaves from Rhododendron spp. with symptoms of Phytophthora infection were sampled from a total of seven nurseries during 2011 and 2012 in the spring and the fall (Table 2). In total, 414 isolates were obtained across all locations and dates. Isolates were identified to species using PCR-RFLP and sequencing of the ITS region for confirmation. In total, 11 taxa were observed in these samples (Table 3).

A novel ITS sequence was observed which differed by two single nucleotide polymorphisms from the closest relative ( $P$. syringae)

Table 1. Loci amplified in this study along with their primers, polymerase chain reaction conditions, and citations ${ }^{\mathrm{a}}$

\begin{tabular}{|c|c|c|c|c|}
\hline Locus & Primers $^{\mathbf{b}}$ & $\mathbf{M g C l}_{2}(\mathbf{m M})$ & Annealing $\left({ }^{\circ} \mathrm{C}\right)$ & Reference \\
\hline ITS & ITS6, ITS4 & 1.5 & 54 & 19 \\
\hline $\operatorname{coxI}$ & FM84, FM85 & 3.0 & 52 & 28 \\
\hline coxII \& spacer & FM75, FM80 & 3.0 & 53 & 28 \\
\hline$\beta$-Tubulin & Btub-F1, Btub-R1 & 1.5 & 54 & 5 \\
\hline
\end{tabular}

a A supplementary table with restriction size data and GenBank accessions is deposited at figshare (24).

b ITS = internal transcribed spacer. 
found in GenBank (e.g., HQ643357). In order to assess whether these samples were $P$. syringae or a new species, the $\beta$-tubulin gene as well as a region including coxII and a spacer were sequenced. The $\beta$-tubulin sequences were identical to other accessions at GenBank identified as $P$. syringae (HQ917875). The coxII with spacer locus was also identical to other accessions identified as $P$. syringae in GenBank (e.g., GU222148 and HQ917883). Based on this information we refer to these samples as a novel $P$. syringae genotype based on two diagnostic single-nucleotide polymorphisms (SNP).

One sample we observed we have referred to as P. lacustris-like but this name may have been misleading. This sample differed from $P$. lacustris (AF266793) and P. riparia (JQ626594.1) by six and seven SNP, respectively. Our use of a "-like" designation here provides a name with which to refer to this sample. However, this naming convention may not accurately reflect its taxonomic relation to these taxa and may be an interesting focus of future research.

Six samples from nursery $\mathrm{E}$ had sequence similarity to $P$. parsiana. However, they were sufficiently different ( $<99 \%$ similarity) that we did not feel it was appropriate to refer to them with a "-like" designation. Instead, we refer to these samples by the year and county they were collected from: $P$. Marion-2012.

A PCR-RFLP assay for Phytophthora taxa expected to occur in nurseries was developed. In total, 24 sequences from 23 Phytophthora taxa were obtained from NCBI, as well as four novel sequences, and queried for restriction enzyme fragment patterns (24). This resulted in the enzyme AciI (5'-C CGC-3') being chosen as the most diagnostic enzyme (Fig. 1). A single, uniquely diagnostic fingerprint was observed for the taxa $P$. hibernalis, $P$. plurivora, $P$. Marion-2012, and $P$. taxon Pgchlamydo. We observed a fragment at approximately $600 \mathrm{bp}$ for $P$. hibernalis, which was not predicted by Geneious (Fig. 1). This fragment was observed in all 71 samples for this taxon, indicating that this result is reproducible and, therefore, has utility in a diagnostic assay. Digestion of $P$. syringae samples resulted in four unique banding patterns not observed for any other species (Fig. 1). Three of these were the product of a codominant $\mathrm{C} / \mathrm{T}$ transversion while the fourth was due to an $\mathrm{A} / \mathrm{G}$ transition. All four of these fingerprints were unique to $P$. syringae. Several other taxa shared banding patterns which were unique to a small set

Table 2. Sample and date of nurseries ${ }^{\mathrm{a}}$

\begin{tabular}{llcccc}
\hline Nursery & County & Spring 2011 & Fall 2011 & Spring 2012 & Fall 2012 \\
\hline A & Washington & March & $\ldots$ & $\ldots$ & December \\
B & Yamhill & April & $\ldots$ & $\ldots$ & November \\
C & Clackamas & $\ldots$ & November & April & $\ldots$ \\
D & Marion & $\ldots$ & November & March & March \\
E & Marion & $\ldots$ & November & March \\
F & Clackamas & $\ldots$ & $\ldots$ & April & November \\
G & Linn & $\ldots$ & $\ldots$ & December \\
\hline
\end{tabular}

a The sampling goal was to visit each nursery during both spring and fall. The month of each visit is presented in the cell for each date and nursery visit.

Table 3. Abundance ranked counts of Phytophthora taxa observed in seven Oregon nurseries

\begin{tabular}{|c|c|c|c|c|c|c|c|c|c|}
\hline \multirow[b]{2}{*}{ Phytophthora spp. } & \multicolumn{7}{|c|}{ Nurseries } & \multirow[b]{2}{*}{ Sum } & \multirow[b]{2}{*}{ Observations in nurseries } \\
\hline & $\mathbf{A}$ & B & $\mathbf{C}$ & D & $\mathbf{E}$ & $\mathbf{F}$ & $\mathbf{G}$ & & \\
\hline P. syringae & 49 & 15 & 6 & 37 & 2 & 21 & 46 & 176 & 7 \\
\hline P. plurivora & 16 & 21 & 52 & 3 & 0 & 13 & 15 & 120 & 6 \\
\hline P. pini/citricola III & 0 & 0 & 0 & 13 & 0 & 2 & 9 & 24 & 3 \\
\hline P. taxon Pgchlamydo & 0 & 1 & 0 & 0 & 0 & 2 & 7 & 10 & 3 \\
\hline P. hibernalis & 0 & 71 & 0 & 0 & 0 & 0 & 0 & 71 & 1 \\
\hline P. Marion-2012 & 0 & 0 & 0 & 0 & 6 & 0 & 0 & 6 & 1 \\
\hline P. riparia & 0 & 0 & 0 & 0 & 0 & 0 & 3 & 3 & 1 \\
\hline P. bilorbang & 0 & 0 & 0 & 0 & 0 & 0 & 1 & 1 & 1 \\
\hline P. cactorum & 0 & 0 & 0 & 0 & 0 & 0 & 1 & 1 & 1 \\
\hline P. hedraiandra & 1 & 0 & 0 & 0 & 0 & 0 & 0 & 1 & 1 \\
\hline P. lacustris-like & 0 & 0 & 0 & 0 & 1 & 0 & 0 & 1 & 1 \\
\hline Total & 66 & 108 & 58 & 53 & 9 & 38 & 82 & 414 & 7 \\
\hline
\end{tabular}
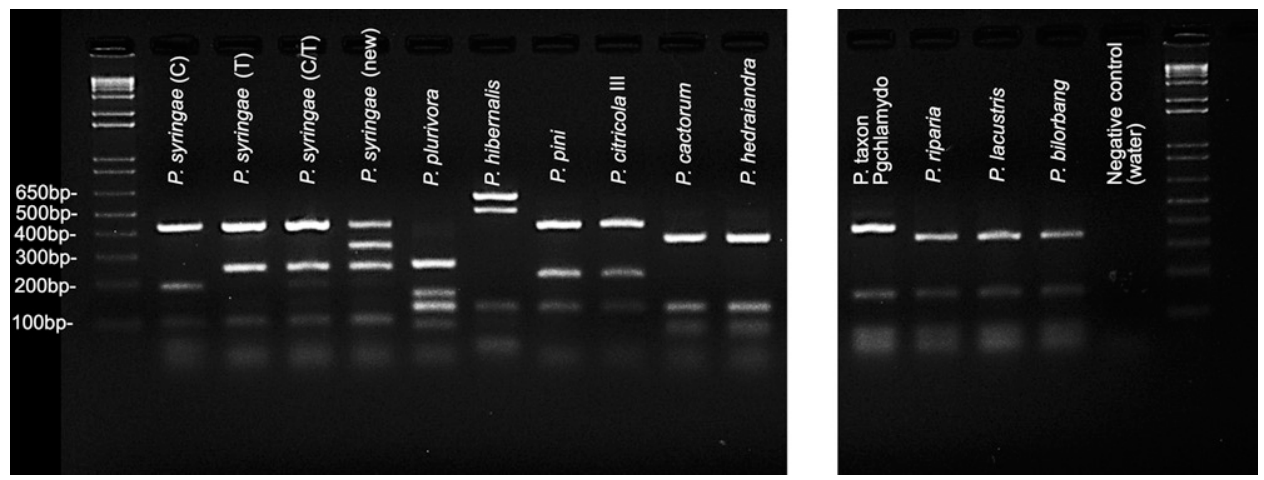

Fig. 1. Gel image demonstrating diagnostic differences among Phytophthora taxa. Polymerase chain reaction amplicons of the internal transcribed spacer region were digested with the enzyme Acil and resolved on a 2\% agarose gel. A 1-kb-plus DNA ladder is shown in the first and last lanes. See documentation deposited at figshare for further information (24). 
of taxa but distinguished this small set from the other taxa. $P$. pini and $P$. citricola III shared a banding pattern which could not distinguish among these two taxa. These taxa also share an identical ITS sequence (21). Due to this close genetic relatedness, we did not further pursue attempts to distinguish these taxa. $P$. hedraiandra and $P$. cactorum shared a banding pattern which was unique to these two taxa but invariable between them. Digestion of ITS with AluI (5'-AG'CT-3') resulted in fingerprints which differentiate these taxa. A single banding pattern based on ITS digested with Acil was shared among P. bilorbang, $P$. lacustris, and P. riparia. Amplification of the coxI gene in P. lacustris, $P$. riparia, and $P$. bilorbang resulted in an amplicon of approximately 685 bp. Digestion with $M n l I\left(5^{\prime}-\mathrm{CCTC}(\mathrm{N}) 7^{\wedge}-3^{\prime}\right)$ and $B s r \mathrm{I}$ $\left(5^{\prime}\right.$-ACTGGN $\left.{ }^{\wedge}-3^{\prime}\right)$ resulted in fragments for all taxa which were different from the other two taxa, resulting in a diagnostic assay (Fig. 2). A supplementary table with restriction size data and GenBank accessions is deposited at figshare (24).

Incidence and abundance of foliar Phytophthora spp. varied dramatically among nurseries as well as among seasons for most nurseries (Fig. 3). The most abundant taxon was P. syringae ( $42.5 \%$ of all

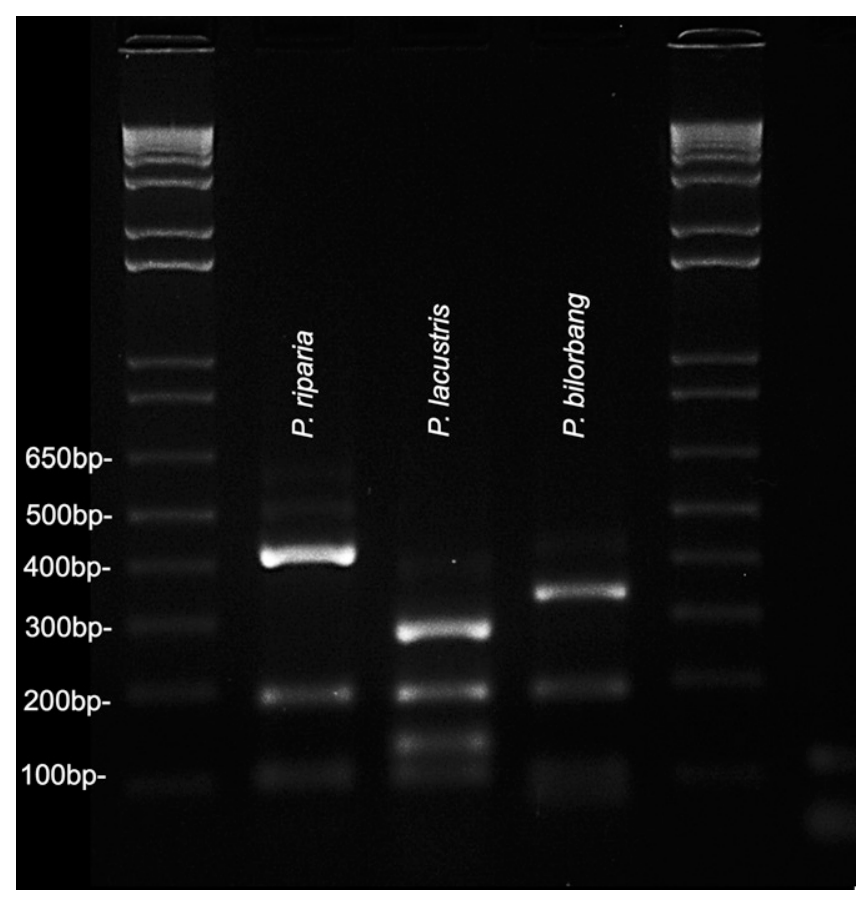

Fig. 2. Gel image demonstrating diagnostic differences among Phytophthora taxa. The coxl gene digested with $\mathrm{Mnll}$ and Bsrl distinguishes Phytophthora riparia, P. lacustris, and $P$. bilorbang. All products resolved on a $2 \%$ agarose gel with a $1-\mathrm{kb}$-plus DNA ladder shown in lane 1. See documentation deposited at figshare for further information (24). isolates), which was observed in every nursery at almost every season (Table 3). Although it was abundant in nurseries A, D, and G (74.2, 69.8 , and $56.1 \%$ of isolates within each nursery, respectively), it was rare in nurseries $\mathrm{C}$ and $\mathrm{E}$ (10.3 and $22.2 \%$ of isolates within each nursery, respectively). The second most abundant taxon, $P$. plurivora ( $29 \%$ of all isolates), was abundant in nursery $\mathrm{C}$ ( $89.7 \%$ of isolates observed in nursery $\mathrm{C})$, moderately abundant in nurseries A, B, $\mathrm{F}$, and $\mathrm{G}(24.2,19.4,34.2$, and $18.3 \%$ of isolates observed in each nursery, respectively) but absent from nursery E. The third most abundant taxon, $P$. hibernalis ( $17.1 \%$ of all isolates), occurred at relatively high abundance in nursery B $(65.7 \%$ of isolates observed in nursery B) but did not occur in the other nurseries. The remaining taxa were relatively rare. Species richness ranged from two to seven species per nursery.

Diversity of foliar Phytophthora communities within each nursery varied dramatically. Shannon-Wiener indices ranged from 0.124 to 1.587 while evenness ranged from 0.179 to 0.874 (for samples with more than one observed taxon; Table 4). This represented a range of close to $70 \%$ of its theoretical range. Similarly, Simpson's index demonstrated a broad range of values from 0.053 to 0.750 (Table 4). Because Simpson's index is a probability, it ranges from zero to one. The range of Simpson's indices observed in Table 4 includes almost the entire theoretical range of this index. Differences among season for certain nurseries were evident as well. For example, nurseries D, F, and G increased diversity in fall; nursery B decreased diversity in the fall; and nursery A demonstrated no relevant change. It is also noteworthy that abundance is not necessarily correlated with diversity. Nursery $\mathrm{C}$ (a nursery where $P$. plurivora was dominant) had a moderate number of isolates (58 isolates) but one of the lowest diversities (Table 4). Nursery E had a low number of isolates detected but demonstrated a relatively high diversity. However, nursery B did have the largest number of isolates detected and demonstrated a relatively high diversity, in line with the idea that abundance may contribute to diversity.

Differences in diversities among nurseries and among seasons within nurseries were statistically significant (Table 5). Total diversity was not statistically significant because this category encompasses the entire sample, such that reassigning isolates to other groupings does not affect this estimate. Within-nursery diversities were statistically significant, with a negative z-value, indicating less observed diversity in part of our sample relative to a sample assuming a uniform distribution of diversity (Table 5). This pattern is likely driven by nurseries $\mathrm{F}$ and $\mathrm{G}$, which had a relatively large amount of diversity, as well as nurseries $\mathrm{A}$ and $\mathrm{C}$, which had relatively low diversity (Table 4). Differences in diversity among nurseries as well as differences in diversities among season within nurseries were both significant (Table 5). Nurseries B, D, and G had the greatest differences in diversity among seasons (Table 4). Note that, whereas isolate number for nursery $\mathrm{G}$ was similar among seasons (Table 5, Fig. 3), the diversity in spring was much less than in the fall. Nurseries $\mathrm{A}$ and $\mathrm{C}$ showed relatively little change in diversity among

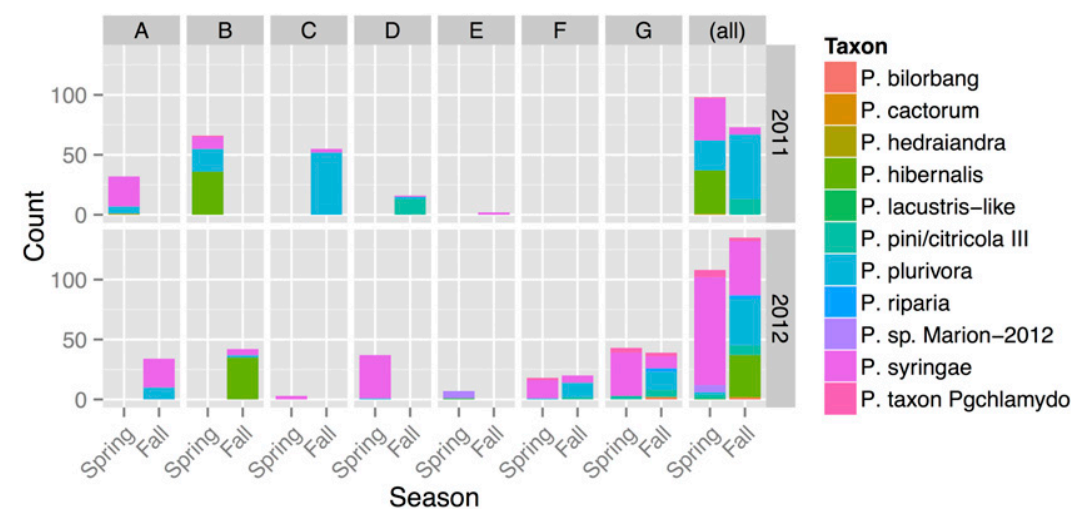

Fig. 3. Bar plot of Phytophthora spp. incidence. Nurseries A to $G$ are in columns with season (spring and fall) in subcolumns. Year sampled is presented in rows per nursery. 
seasons (Table 4), noting that, again for nursery $\mathrm{C}$, abundance changed dramatically (Fig. 3) but the diversity estimates were very similar (Table 4). The majority of the Phytophthora spp. diversity within the nurseries sampled was contained within seasons and nurseries while among-nursery diversity accounted for the third greatest component (Table 5).

\section{Discussion}

Characterizing the Phytophthora communities in nurseries represents an important first step in management of these pathogens. Regulated pathogens such as $P$. ramorum represent a significant financial burden to a nursery when discovered and have been shown to be moved by nursery shipments $(13,15,17,30)$. Foliar symptoms of $P$. ramorum cannot currently be distinguished from other foliar $P$ hytophthora symptoms. Similarly, some taxa may create lesions but lack the pathogenicity or dispersal capabilities of other taxa, making their presence less critical. Understanding the communities of Phytophthora in nurseries builds prior expectations on which taxa to find commonly, provides information on what diagnostic assays need to be developed, and provides critical information for implementation of systems approaches (35).

We found that foliar Phytophthora communities on Rhododendron spp. in Oregon nurseries differed significantly among nursery as well as among season within nurseries (Table 5). This indicates that, on any visit to any nursery, one may expect to encounter a

Table 4. Phytophthora community diversity summaries for seven Oregon nurseries

\begin{tabular}{llrcccc}
\hline Nursery & Season & $\boldsymbol{n}^{\mathbf{a}}$ & Richness $^{\mathbf{b}}$ & Shannon $^{\mathbf{c}}$ & Evenness $^{\mathbf{d}}$ & Simpson $^{\mathbf{e}}$ \\
\hline A & All & 66 & 3 & 0.628 & 0.572 & 0.390 \\
A & Spring & 32 & 3 & 0.615 & 0.560 & 0.354 \\
A & Fall & 34 & 2 & 0.606 & 0.874 & 0.415 \\
B & All & 108 & 4 & 0.912 & 0.658 & 0.511 \\
B & Spring & 66 & 4 & 1.038 & 0.749 & 0.596 \\
B & Fall & 42 & 3 & 0.550 & 0.501 & 0.289 \\
C & All & 58 & 2 & 0.333 & 0.480 & 0.185 \\
C & Spring & 3 & 1 & $\ldots$ & $\ldots$ & $\ldots$ \\
C & Fall & 55 & 2 & 0.212 & 0.305 & 0.103 \\
D & All & 53 & 3 & 0.758 & 0.690 & 0.449 \\
D & Spring & 37 & 2 & 0.124 & 0.179 & 0.053 \\
D & Fall & 16 & 3 & 0.602 & 0.548 & 0.320 \\
E & All & 9 & 3 & 0.849 & 0.773 & 0.494 \\
E & Spring & 7 & 2 & 0.410 & 0.592 & 0.245 \\
E & Fall & 2 & 1 & $\ldots$ & $\ldots$ & $\ldots$ \\
F & All & 38 & 4 & 1.005 & 0.725 & 0.572 \\
F & Spring & 18 & 3 & 0.557 & 0.507 & 0.290 \\
F & Fall & 20 & 3 & 0.898 & 0.817 & 0.540 \\
G & All & 82 & 7 & 1.316 & 0.676 & 0.631 \\
G & Spring & 43 & 3 & 0.555 & 0.506 & 0.286 \\
G & Fall & 39 & 7 & 1.587 & 0.816 & 0.750 \\
\hline
\end{tabular}

a Sample size.

b Number of observed taxa.

c Shannon-Wiener index.

d Shannon-Wiener index scaled richness, such that it ranges from 0 to 1 .

e Simpson's index or the probability that two individuals drawn from the sample are different taxa.

${ }^{\mathrm{f}}$ Diversities are not presented when only one taxon was observed. different Phytophthora community, even on visits to the same nursery but during different times of the year (Fig. 3). This indicates that individuals interested in inspecting nurseries for Phytophthora communities should conduct more than one sampling per year. For example, visits to nursery B resulted in a high frequency of $P$. hibernalis (Table 3; Fig. 3), a finding not observed in the other nurseries. Similarly, a visit to nursery D in the fall may result in a high abundance of $P$. pini/P. citricola III while a visit in spring may result in a high abundance of $P$. syringae. Despite these marked differences, some generalizations can be made. The most abundant foliage-infecting taxon was $P$. syringae, which was observed in every sampled nursery (Table 3). Similarly, $P$. plurivora was observed in almost every nursery (Table 3 ). The third most commonly observed taxon, $P$. pinil $P$. citricola III, was observed in moderate abundance but at only three of the seven nurseries (Table 3 ). The regulated taxon $P$. ramorum was not observed in any of the sampled nurseries. This suggests that any leaf lesion observed on Rhododendron spp. in an Oregon nursery which appears to be due to a Phytophthora infection is likely to not be $P$. ramorum and that $P$. syringae and $P$. plurivora are more likely candidates.

Our work shares commonalities and differences with previously published reports. Some comparisons are not straightforward due to recent nomenclatural changes. For example, the taxon $P$. citricola has been divided into $P$. citricola III, $P$. multivora, $P$. plurivora, and $P$. pini $(21,23,42)$. Schwingle et al. (41) surveyed 45 Minnesota nurseries in 2002 and 2003 and found five Phytophthora taxa on Rhododendron leaves, with $P$. cactorum as the most abundant, followed by $P$. citricola and $P$. citrophthora. They further reported surveys from 12 Minnesota nurseries in 2004 and 10 nurseries in 2005 where they found five Phytophthora taxa on Rhododendron spp., with P. citricola the most abundant and the others rare. Warfield et al. surveyed 14 nurseries in North Carolina during 2003 (47). They detected three species of Phytophthora on Rhododendron spp. and found P. citricola and $P$. cambivora to be the most abundant while $P$. cactorum was rare. Donahoo and Lamour surveyed 29 Tennessee nurseries during 2004 and 2005 (9). They detected seven Phytophthora taxa, with $P$. citricola as the most frequently isolated Phytophthora sp. derived from Rhododendron leaves and $P$. citrophthora and $P$. nicotianae as second and third most common. Yakabe et al. reported Phytophthora taxa recovered from leaf samples from 1,619 nurseries in California during 2005 and 2006 (49). They observed eight Phytophthora taxa on Rhododendron spp. (including azalea), with $P$. citricola, $P$. foliorum, and $P$. syringae as similarly abundant and the remaining taxa being relatively rare. Bienapfl and Balci (4) surveyed 10 Maryland nurseries over a 3-year period (2010 to 2012). Their survey not only included samples from each nursery but also included samples which had recently arrived at the nurseries, typically from West Coast suppliers. They reported the detection of 10 Phytophthora taxa associated with Rhododendron spp., with P. cinnamomi, $P$. citrophthora, $P$. pini, $P$. plurivora, and $P$. multivora being abundant and the remaining taxa relatively rare. Among plants which had recently been shipped to Maryland nurseries, they detected six Phytophthora taxa associated with Rhododendron spp., with P. plurivora, $P$. pini, and $P$. citrophthora being abundant and the remaining taxa rare. Parke et al. surveyed four Oregon nurseries repeatedly over the 4 years 2006 to 2009 (36). They reported 16 taxa on plant tissues, with $P$. plurivora and $P$. syringae being found at all four nurseries, $P$. cinnamomi and $P$. citrophthora being abundant,

Table 5. Hierarchical partitioning of the Shannon-Wiener index of diversity

\begin{tabular}{|c|c|c|c|c|c|c|c|}
\hline Partition & Statistic & $\mathbf{Z}$ & Mean2 & $2.5 \%{ }^{a}$ & $50 \%{ }^{a}$ & $97.5 \%{ }^{a}$ & $P$ value \\
\hline Total & 1.435 & 0.000 & 1.435 & 1.435 & 1.435 & 1.435 & 1.000 \\
\hline Within nursery & 0.853 & -54.025 & 1.373 & 1.352 & 1.374 & 1.390 & 0.001 \\
\hline Within season ${ }^{\mathrm{b}}$ & 0.663 & -52.171 & 1.322 & 1.296 & 1.323 & 1.345 & 0.001 \\
\hline Among nursery & 0.582 & 54.025 & 0.063 & 0.046 & 0.062 & 0.083 & 0.001 \\
\hline Among season ${ }^{b}$ & 0.190 & 15.251 & 0.050 & 0.034 & 0.050 & 0.071 & 0.001 \\
\hline
\end{tabular}

\footnotetext{
a Percentiles from 999 permutations to test significance.
}

b These levels are nested within nursery. 
and the remaining taxa rare. Common to all these reports was the presence of taxa within the $P$. citricola complex. Although $P$. syringae was common in our surveys, the only other reports to find this taxon as abundant were the other U.S. west coast reports of Yakabe et al. (49) and Parke et al. (36). Perhaps the most notable difference in our report was $P$. citrophthora, which was frequently abundant in other surveys but absent in ours. $P$. citrophthora is thought to be adapted to warmer climates than found in the Pacific Northwest. Similar work conducted in European nurseries showed similar patterns of Phytophthora sp. distributions $(31,39)$.

Here, we've presented a characterization of the Phytophthora communities present in Oregon nurseries, an important first step in implementing knowledge-based management systems (35). Current methods for identification of Phytophthora spp. in nurseries consist of culturing on selective media (22) or an enzyme-linked immunosorbent assay test (1). These tests typically validate whether a sample can be attributed to an organism in the genus Phytophthora but do not diagnose the species. Determination at the species level typically requires more expensive molecular genetic tools $(19,27)$, which typically are developed to address only taxa which are legally regulated (e.g., P. ramorum). Therefore, knowledge of the species contributing to a community of Phytophthora may not only aid in speciesspecific management strategies but also help researchers prioritize which taxa to focus on during efforts to develop cost-effective marker systems. Our research demonstrates a great amount of heterogeneity among Oregon nurseries. Although some taxa appear ubiquitous (i.e., $P$. syringae and $P$. plurivora), much of the observed diversity is localized to one or a few nurseries. This suggests that, as more nurseries are surveyed, a greater amount of Phytophthora diversity may be discovered. This work marks an important contribution toward a better knowledge of the Phytophthora communities in nurseries and provides a framework for determining which Phytophthora communities can be expected in Pacific Northwest nurseries on Rhododendron.

\section{Acknowledgments}

This project was supported by funds from USDA-ARS CRIS Project 535822000-039-00D, the USDA-ARS Floriculture Nursery Initiative, the USDA ARS NW Center for Nursery Crops, and the Oregon Department of Agriculture/Oregon Association of Nurseries (ODA-OAN) research programs. We thank K. Fairchild, M. Larsen, C. Press, and K. Bellingham for technical and administrative support.

\section{Literature Cited}

1. Ali-Shtayeh, M. S., MacDonald, J. D., and Kabashima, J. 1991. A method for using commercial ELISA tests to detect zoospores of Phytophthora and Pythium species in irrigation water. Plant Dis. 75:305-311.

2. Altschul, S. F., Gish, W., Miller, W., Myers, E. W., and Lipman, D. J. 1990. Basic local alignment search tool. J. Mol. Biol. 215:403-410.

3. Becker, R. A., and Wilks, A. R. 1993. Maps. In: AT\&T Bell Lab. Stat. Res. Rep. 93.2.

4. Bienapfl, J. C., and Balci, Y. 2014. Movement of Phytophthora spp. in Maryland's Nursery trade. Plant Dis. 98:134-144.

5. Blair, J. E., Coffey, M. D., Park, S.-Y., Geiser, D. M., and Kang, S. 2008. A multi-locus phylogeny for Phytophthora utilizing markers derived from complete genome sequences. Fungal Genet. Biol. 45:266-277.

6. Brasier, C. M., Kirk, S. A., Delcan, J., Cooke, D. E. L., Jung, T., and Man In't Veld, W. A. 2004. Phytophthora alni sp. nov. and its variants: Designation of emerging heteroploid hybrid pathogens spreading on Alnus trees. Mycol. Res. 108:1172-1184.

7. Camele, I., Marcone, C., and Cristinzio, G. 2005. Detection and identification of Phytophthora species in southern Italy by RFLP and sequence analysis of PCR-amplified nuclear ribosomal DNA. Eur. J. Plant Pathol. 113: $1-14$.

8. Crist, T. O., Veech, J. A., Gering, J. C., and Summerville, K. S. 2003. Partitioning species diversity across landscapes and regions: A hierarchical analysis of alpha, beta, and gamma diversity. Am. Nat. 162:734-743.

9. Donahoo, R. S., and Lamour, K. H. 2008. Characterization of Phytophthora species from leaves of nursery woody ornamentals in Tennessee. HortScience 43:1833-1837.

10. Erwin, D. C., and Ribeiro, O. K. 1996. Phytophthora Diseases Worldwide. American Phytopathological Society, St. Paul, MN.

11. Goss, E. M., Cardenas, M. E., Myers, K., Forbes, G. A., Fry, W. E., Restrepo, S., and Grünwald, N. J. 2011. The plant pathogen Phytophthora andina emerged via hybridization of an unknown Phytophthora species and the Irish potato famine pathogen, P. infestans. PLoS One 6:e24543.
12. Goss, E. M., Larsen, M., Chastagner, G. A., Givens, D. R., and Grünwald, N. J. 2009. Population genetic analysis infers migration pathways of Phytophthora ramorum in US nurseries. PLoS Pathog. 5:e1000583.

13. Goss, E. M., Larsen, M., Vercauteren, A., Werres, S., Heungens, K., and Grünwald, N. J. 2011. Phytophthora ramorum in Canada: Evidence for migration within North America and from Europe. Phytopathology 101: 166-171.

14. Griesbach, J. A., Parke, J. L., Chastagner, G. A., Grünwald, N. J., and Aguirre, J. 2012. Safe Procurement and Production Manual. Oregon Association of Nurseries, Wilsonville.

15. Grünwald, N. J., Garbelotto, M., Goss, E. M., Heungens, K., and Prospero, S 2012. Emergence of the sudden oak death pathogen Phytophthora ramorum. Trends Microbiol. 20:131-138.

16. Grünwald, N. J., Goodwin, S. B., Milgroom, M. G., and Fry, W. E. 2003. Analysis of genotypic diversity data for populations of microorganisms. Phytopathology 93:738-746.

17. Grünwald, N. J., Goss, E. M., and Press, C. M. 2008. Phytophthora ramorum A pathogen with a remarkably wide host range causing sudden oak death on oaks and ramorum blight on woody ornamentals. Mol. Plant Pathol. 9: 729-740.

18. Grünwald, N. J., Kitner, M., McDonald, V., and Goss, E. M. 2008 Susceptibility in Viburnum to Phytophthora ramorum. Plant Dis. 92: 210-214.

19. Grünwald, N. J., Martin, F. N., Larsen, M. M., Sullivan, C. M., Press, C. M., Coffey, M. D., Hansen, E. M., and Parke, J. L. 2011. Phytophthora-ID.org: A sequence-based Phytophthora identification tool. Plant Dis. 95:337-342.

20. Hansen, E. M., Parke, J. L., and Sutton, W. 2005. Susceptibility of Oregon forest trees and shrubs to Phytophthora ramorum: A comparison of artificial inoculation and natural infection. Plant Dis. 89:63-70.

21. Hong, C., Gallegly, M. E., Richardson, P. A., and Kong, P. 2011. Phytophthora pini Leonian resurrected to distinct species status. Mycologia 103:351-360.

22. Jeffers, S. N., and Martin, S. B. 1986. Comparison of two media selective for Phytophthora and Pythium species. Plant Dis. 70:1038-1043.

23. Jung, T., and Burgess, T. I. 2009. Re-evaluation of Phytophthora citricola isolates from multiple woody hosts in Europe and North America reveals a new species, Phytophthora plurivora sp. nov. Persoonia 22:95-110.

24. Knaus, B. J., Fieland, V. J., Graham, K. A., and Grünwald, N. J. 2014. Excel file with PCR-RFLP patterns for identification of nursery Phytophthora spp. Online publication. http://dx.doi.org/10.6084/m9.figshare.1153948

25. Lande, R. 1996. Statistics and partitioning of species diversity, and similarity among multiple communities. Oikos 76:5-13.

26. Magurran, A. E. 1988. Ecological Diversity and Its Measurement. Online publication. Springer Dordrecht, The Netherlands. http://dx.doi.org/10.1007/97894-015-7358-0

27. Martin, F. N., Abad, Z. G., Balci, Y., and Ivors, K. 2012. Identification and detection of Phytophthora: Reviewing our progress, identifying our needs. Plant Dis. 96:1080-1103.

28. Martin, F. N., and Tooley, P. W. 2003. Phylogenetic relationships among Phytophthora species inferred from sequence analysis of mitochondrially encoded cytochrome oxidase I and II genes. Mycologia 95:269-284.

29. Martin, F. N., and Tooley, P. W. 2004. Identification of Phytophthora isolates to species level using restriction fragment length polymorphism analysis of a polymerase chain reaction-amplified region of mitochondrial DNA. Phytopathology 94:983-991.

30. Mascheretti, S., Croucher, P. J. P., Vettraino, A., Prospero, S., and Garbelotto, M. 2008. Reconstruction of the sudden oak death epidemic in California through microsatellite analysis of the pathogen Phytophthora ramorum. Mol. Ecol. 17:2755-2768.

31. Moralejo, E., Pérez-Sierra, A. M., Álvarez, L. A., Belbahri, L., Lefort, F., and Descals, E. 2009. Multiple alien Phytophthora taxa discovered on diseased ornamental plants in Spain. Plant Pathol. 58:100-110.

32. Oksanen, J., Blanchet, F. G., Kindt, R., Legendre, P., Minchin, P. R., Simpson, G. L., Solymos, P., Stevens, M. H. H., and Wagner, H. 2013. Vegan: Community ecology package. $\mathrm{R}$ package version $2.0-7$. Online publication. http://vegan.r-forge.r-project.org/

33. Oregon Department of Agriculture. 2008. Oregon Agriculture: Facts and Figures. Online: http://library.state.or.us/repository/2010/201010121527412/2007.pdf

34. Oregon Department of Agriculture. 2012. Oregon Agriculture: Facts and Figures. Online: http://library.state.or.us/repository/2010/201010121527412/2011.pdf

35. Parke, J. L., and Grünwald, N. J. 2012. A systems approach for management of pests and pathogens of nursery crops. Plant Dis. 96:1236-1244.

36. Parke, J. L., Knaus, B. J., Fieland, V. J., Lewis, C., and Grünwald, N. J. 2014 Phytophthora community structure analyses in Oregon nurseries inform systems approaches to disease management. Phytopathology 104:1052-1062.

37. Parke, J. L., Linderman, R. G., Osterbauer, N. K., and Griesbach, J. A. 2004. Detection of Phytophthora ramorum blight in Oregon nurseries and completion of Koch's postulates on Pieris, Rhododendron, Viburnum and Camellia. Plant Dis. 88:87.

38. Prospero, S., Grünwald, N. J., Winton, L. M., and Hansen, E. M. 2009 Migration patterns of the emerging plant pathogen Phytophthora ramorum on the West coast of the United States of America. Phytopathology 99 739-749. 
39. Prospero, S., Vercauteren, A., Heungens, K., Belbahri, L., and Rigling, D. 2013. Phytophthora diversity and the population structure of Phytophthora ramorum in Swiss ornamental nurseries. Plant Pathol. 62:1063-1071.

40. R Core team. 2014. R: A language and environment for statistical computing. Online publication. http://www.R-project.org/

41. Schwingle, B. W., Smith, J. A., and Blanchette, R. A. 2007. Phytophthora species associated with diseased woody ornamentals in Minnesota nurseries. Plant Dis. 91:97-102.

42. Scott, P. M., Burgess, T. I., Barber, P. A., Shearer, B. L., Stukely, M. J. C., Hardy, G. E. S. J., and Jung, T. 2009. Phytophthora multivora sp. nov., a new species recovered from declining Eucalyptus, Banksia, Agonis and other plant species in Western Australia. Persoonia 22:1-13.

43. Shannon, C. E., and Weaver, W. 1949. The Mathematical Theory of Communication. University of Illinois Press, Urbana.

44. Simpson, E. H. 1949. Measurement of diversity. Nature 163:688
45. Tooley, P. W., Kyde, K. L., and Englander, L. 2004. Susceptibility of selected ericaceous ornamental host species in Phytophthora ramorum. Plant Dis. 88 993-999.

46. Van Poucke, K., Franceschini, S., Webber, J. F., Vercauteren, A., Turner, J. A., McCracken, A. R., Heungens, K., and Brasier, C. M. 2012. Discovery of a fourth evolutionary lineage of Phytophthora ramorum: EU2. Fungal Biol. 116:1178-1191.

47. Warfield, C. Y., Benson, D. M., and Hwang, J. 2008. Phytophthora blight and dieback in North Carolina nurseries during a 2003 survey. Plant Dis. 92: 474-481.

48. Werres, S., Marwitz, R., Veld, W., De Cock, A., Bonants, P. J. M., De Weerdt, M., Themann, K., Ilieva, E., and Baayen, R. P. 2001. Phytophthora ramorum sp. nov., a new pathogen on Rhododendron and Viburnum. Mycol. Res. 105:1155-1165.

49. Yakabe, L. E., Blomquist, C. L., Thomas, S. L., and MacDonald, J. D. 2009 Identification and frequency of Phytophthora species associated with foliar diseases in California ornamental nurseries. Plant Dis. 93:883-890. 